\title{
Olfactory and Respiratory Epithelia in the Snake, Elaphe quadrivirgata.
}

\section{By \\ Nobuharu IWAHORI, Etsuko KIYOTA and Kaori NAKAMURA}

Department of Anatomy, Faculty of Medicine, Nagasaki University, Nagasaki 852, Japan

-Received for Publication, June 22, 1987-

Key words: olfactory and respiratory epithelia, snake, Golgi and Nissl methods.

\begin{abstract}
Summary: The structure of the olfactory and respiratory epithelia of the snake was studied using the rapid Golgi and the Nissl methods. The olfactory epithelium was a pseudostratified columnar one and was composed of supporting, olfactory and basal cells which were columnar, bipolar spindle and triangular, respectively. The nuclei of these three types of cells were arranged in a laminar pattern: those of the supporting cells were located most superficially, those of the olfactory cells occupied the middle wide zone, while those of the basal cells were arranged in a row at the base of the epithelium. The respiratory epithelium was a ciliated pseudostratified columnar one and was made up of columnar, mucous and basal cells which were cylindrical, goblet-like and triangular, respectively. Thus, the fundamental organization of the olfactory and respiratory epithelia in the snake was similar to that of the olfactory and and respiratory epithelia in various other terrestrial animals.
\end{abstract}

The olfactory and respiratory epithelia of a number of vertebrate species have been documented and the literatures have been reviewed by different investigators (Matthes, '34; Allison, '53; Parsons, '70). However, these epithelia in the snake have been given less attention and most knowledge on the histology of these epithelia comes from a relatively few descriptions (Retzius, 1894; Bellairs, '49; Parsons, '70). In the present study, we attempted to elucidate the structural features of these epithelia in the snake using the rapid Golgi and the Nissl methods.

\section{Materials and Methods}

Approximately 150 embryos and five adult snakes were observed. The cytoarchitecture of the olfactory and respiratory epithelia was studied in the Nissl preparations and morphology of the cells composing these epithelia was analyzed using the rapid Golgi preparations.

For the rapid Golgi method, approximately 140 embryos of $9.13 \mathrm{~cm}$ in body length were used. The embryos were sacrificed by decapitation and the rostral end, including the nasal cavity, was cut into $3 \mathrm{~mm}$ thick slices, using a razor blade. The tissue slices were immersed in an osmium tetroxide-potassium dichromate mixture for two to five days, at room temperature. The

All communication and proofs to: Dr. Nobu haru Iwahori. Department of Anatomy, Faculty of Medicine, Nagasaki University, Nagasaki 852, Japan. 
slices were then washed briefly in a freshly prepared $1 \%$ silver nitrate solution and kept in the same solution for one week. The impregnated tissues were dehydrated in absolute alcohol and embedded in $14 \%$ celloidin. The embedded materials were cut into $90-120 \mu \mathrm{m}$ serial sections, dehydrated in $100 \%$ alcohol, cleared in xylol and mounted in dammar-gum.

For the Nissl preparations, ten embryos of $9-13 \mathrm{~cm}$ in body length and five adult specimens were used. The embryos were sacrificed by decapitation, and the rostral end was fixed in alcohol. The adult specimens were killed by an intraperitoneal injection of over dosis of Nembutal. The animals were perfused intracardially with $10 \%$ formalin and the rostral end was fixed in the same solution. The fixed materials were decalcified, embedded in paraffin, cut into $15 \mu \mathrm{m}$ serial sections and stained with thionin or cresylviolet.

\section{Results}

The cavum nasi proprium in the snake was a simple chamber. As seen in a frontal section, the cavum was a C-shaped space with its hilus oriented ventrolaterally (Fig. 1). A prominent concha projected dorsomedially from the lateral wall. The surface of the cavum was lined with olfactory or respiratory epithelium. The olfactory epithelium covered the dorsal half of the septal wall, roof, dorsal portion of the lateral wall, and dorsal portion of the concha. The respiratory epithelium lined the ventral portion of the septal and lateral wall, and the ventral half of the concha.

\section{Olfactory epithelium (OE)}

As seen in the Nissl preparations, the $\mathrm{OE}$ in the snake was a pseudostratified columnar epithelium. It was somewhat thicker than the neighbouring respiratory epithelium and was further characterized by the presence of olfactory glands (Fig. 1). The $\mathrm{OE}$ in the snake was made up of supporting, olfactory and basal cells and nuclei of these three types of cells were arranged in separate layers. The surface of the $O E$ was usually covered with mucous. The ducts of the olfactory glands penetrated the $\mathrm{OE}$ to open at the epithelial surface.

The supporting cells were long cylindrical ones extending perpendicular to the epithelial surface. The nuclei were oval, located near the surface and arranged in two to four rows which ran in parallel with the free surface of the OE (Plate 1A, NSC). As seen in the Golgi preparations, the supporting cells were columnar ones with a local ovoid swelling by the nucleus at approximately the superficial one third (Fig. 2, SC). Distal to the nuclear swelling, the supporting cells were broad with a smooth contour. In contrast, deep portions of the supporting cells were thin, had a coarse and irregular contour and were occasionally forked in their course.

The olfactory cells lay between the supporting cells. Their round nuclei occupied a wide zone immediately beneath those of the supporting cells (Plate 1A, NOC). In the Golgi preparations, the olfactory cells were bipolar and were arranged perpendicular to the surface (Fig. 2, OC). The cell bodies were spindle and were fitted between the supporting cells in the region which was thin and irregular. The peripheral processes, the dendrites, of the olfactory cells ascended superficially between the supporting cells. At the epithelial surface, the dendrites became somewhat expanded and generated several fine short hairs which extended into the mucous covering the epithelial surface. The proximal processes, the axons, of the olfactory cells travelled deeply and entered the lamina 


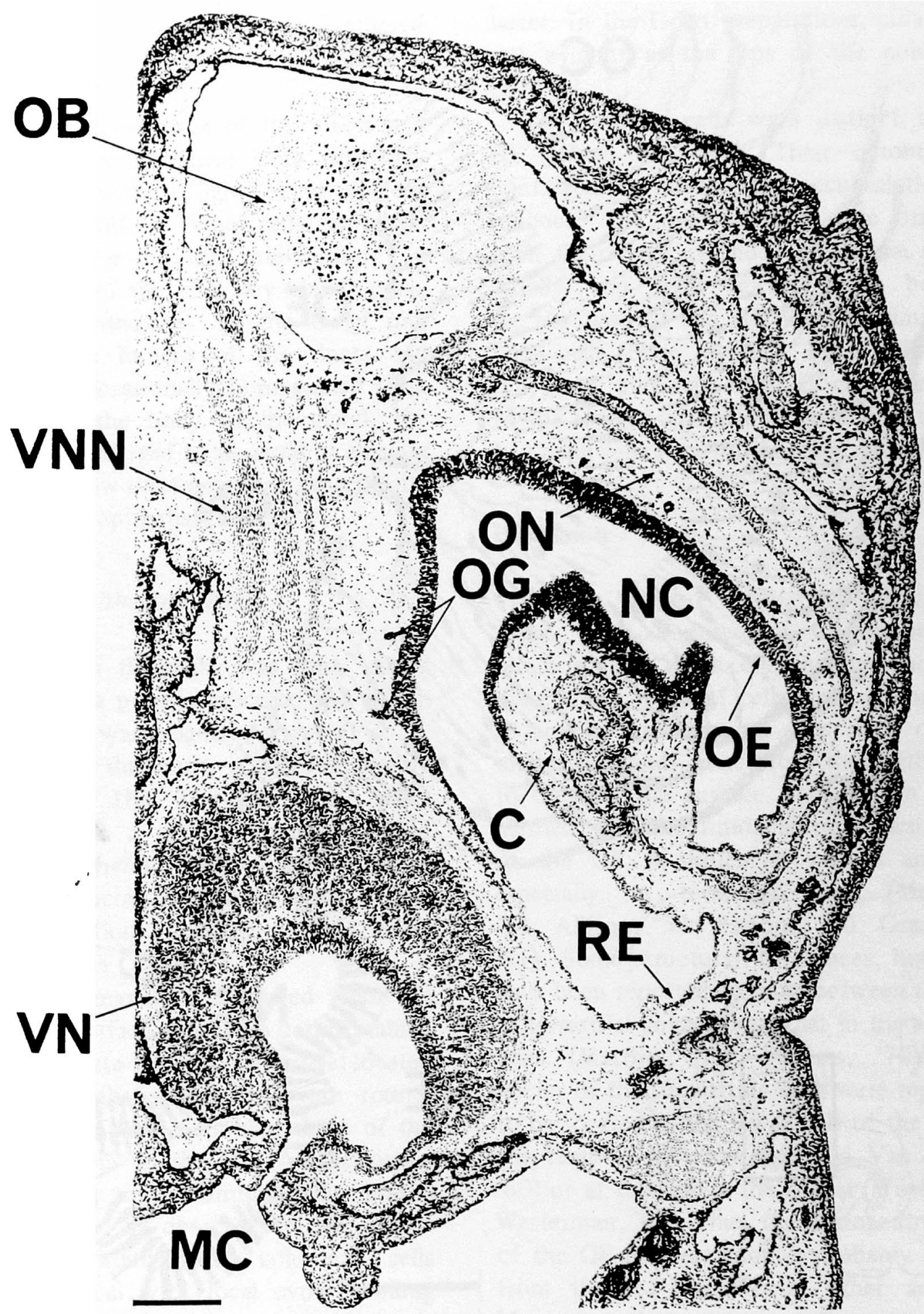

Fig. 1. The nasal cavity (NC) and neighbouring structures of the snake embryo of $13 \mathrm{~cm}$ in body length as seen in a frontal section. The left side of the figure is medial, and the upper, dorsal. The NC is a C-shaped cavity with a concha (C) protruding dorsomedially. The NC is lined with olfactory (OE) or respiratory epithelium (RE). From the $O E$ extend fibers of the olfactory nerves (ON) travelling dorsomedially toward the olfactory bulb (OB). The vomeronasal nerve (VNN) derived from the vomeronasal organ (VN) extends dorsally. MC, mouth cavity. Drawing from a thionin stained section. The scale line is $200 \mu \mathrm{m}$. 


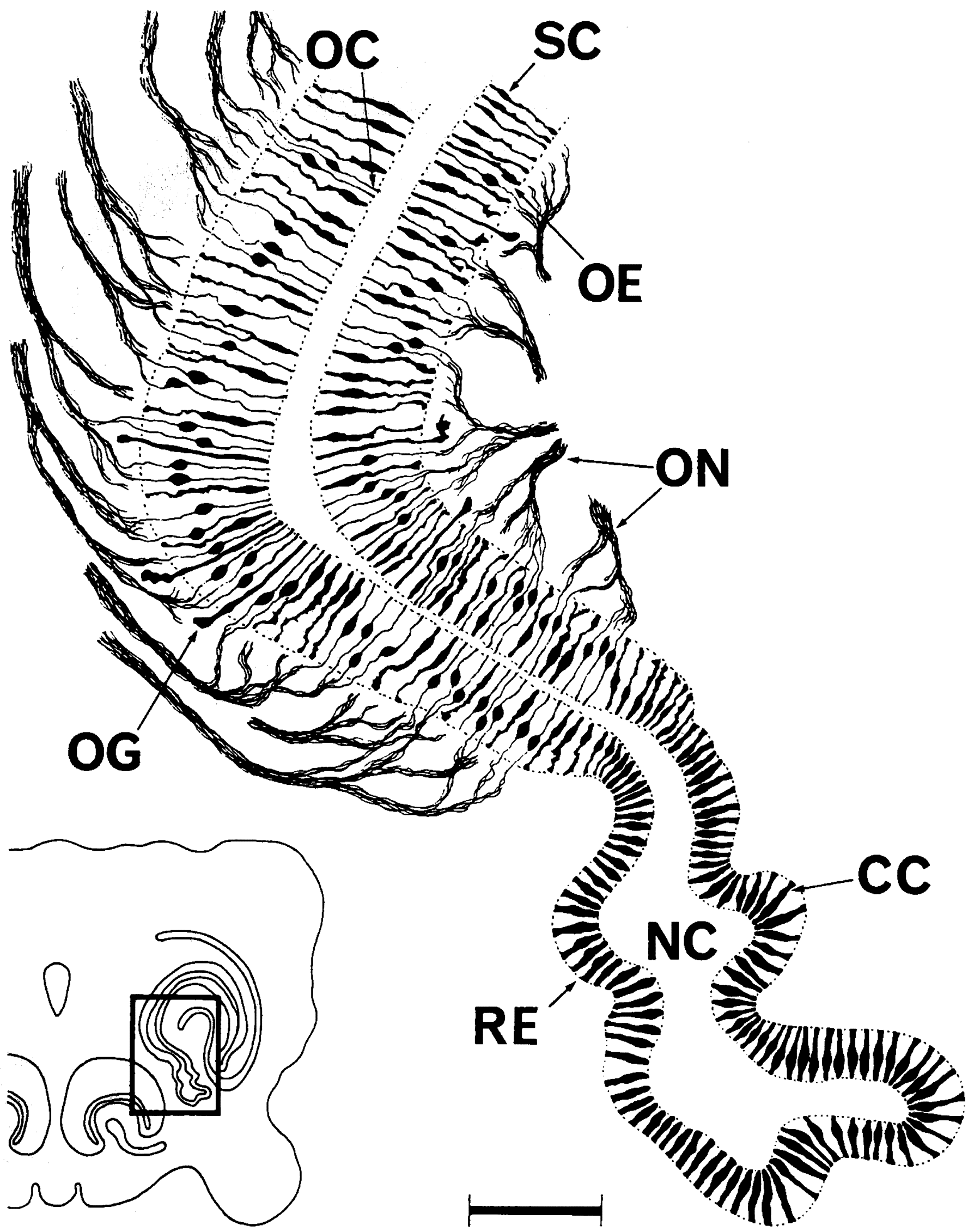

Fig. 2. The olfactory (OE) and respiratory epithelium (RE) of the snake embryo of $13 \mathrm{~cm}$ in body length as seen in the frontal sections. The figure was depicted from the squared area indicated at lower left. The left side of the figure is medial, and the upper, dorsal. In the olfactory mucosa, the olfactory (OC) and supporting cells (SC), and the lumens of the olfactory glands and ducts (OG) are impregnated. The proximal processes of the $\mathrm{OC}$ gather to form bundles of the olfactory nerve (ON). In the RE, columnar cells (CC) are merely impregnated. NC, nasal cavity. Drawing from the Golgi sections. The scale line is $100 \mu \mathrm{m}$. 
propria mucosa where several axons gathered together to form bundles of the olfactory nerve fibers (Fig. 2, ON).

At the deepest zone of the $\mathrm{OE}$ was a row of basal cells. These were small triangular cells with a light ovoid nucleus (Plate 1A, NBC). These cells remained unimpregnated in the Golgi preparations.

The ducts of the olfactory glands penetrated the epithelium. In the Golgi preparations, the lumens of the ducts and glands were occasionally impregnated (Fig. 2, OG). At the body of the gland, the lumens were enlarged to an ovoid or alveolar shape. A narrow duct extended superficially to open at the epithelial surface.

\section{Respiratory epithelium (RE)}

The RE in the snake was thin, resting upon a lamina propria mucosa. The RE in the embryo was slightly wavy (Fig. 2, $\mathrm{RE}$ ), while in the adult, it was remarkably folded (Plate 1B). The RE in the adult specimens was a ciliated pseudostratified columnar epithelium and was composed of columnar, mucous and basal cells. In the Nissl preparations, the RE stained more lightly than the $\mathrm{OE}$.

The columnar cells extended from the base to the surface and had a darkly stained cytoplasm (Plate 1B, CC). The nuclei located near the epithelial surface, were round, stained lightly and resembled those of the supporting cells in the OE. At the superficial tips of the columnar cells, several fine cilia could be observed. As seen in the Golgi preparations, the columnar cells were cylindrical with local ovoid swelling by the nucleus, approximately at the superficial one third (Fig. 2, CC). Although the general morphology of the columnar cells in the RE resembled that of the supporting cells in the $\mathrm{OE}$, the former were thicker and had a more smooth contour than the latter. In the Golgi preparations, cilia were not evident at the tips of the columnar cells.

The mucous cells were distinct in the RE (Plate 1B, MC). Their cytomplasm contained an intracellular accumulation of mucous. The mucous cells were oriented with their large extended cytoplasm superficially and their nuclear zone basally. At the base of the RE were disseminated basal cells (Plate 1B, BC). These cells were polygonal and had a small clear nucleus. In the Golgi preparations, both the mucous and basal cells were not impregnated.

\section{Discussion}

In the present study, the $\mathrm{OE}$ in the snake was composed of the supporting, olfactory and basal cells and the nuclei of these three types of cells were arranged in a laminar organization. The duct of the olfactory glands penetrated the epithelium to open at the surface. It has been documented that the fundamental organization of the $\mathrm{OE}$ is similar in various animals, especially in terrestrial ones (Matthes, '34; Allison, '53; Parsons, '70; Graziadei, '71). Some structural differences, however, have been reported to exist between the $\mathrm{OE}$ in terrestrial animals and that in the aquatic ones (Matthes, '34; Parsons, '70). The nuclei of the supporting cells were reported to be located in the lower half of the OE in the lamprey (Kleerekoper and Van Erkel, '60) or at the base in the teleost (Wilson and Westerman, '67). Thus, the laminar structure of the $\mathrm{OE}$ in these animals probably differs from that of the $\mathrm{OE}$ in other animals. Moreover, the existence of mucous cells and absence of the olfactory glands was noted in the teleostian olfactory mucosa (Wilson and Westerman, '67).

Using the Golgi method, the structure of the $\mathrm{OE}$ was analyzed in the cyclostome, 
fish, amphibia (Retzius, 1892b), reptile (Retzius, 1894), and mammals (Van Gehuchten, 1890; Brunn, 1892; Retzius, 1892a; Ramón y Cajal, '11). In these studies, as in the present study, only the supporting and olfactory cells, and the lumens of the olfactory glands and ducts were impregnated. Although the impregnation mechanisms of the Golgi method have not been fully elucidated, this fact suggests some characteristic differences between the supporting and olfactory cells, and the basal cells. Morphology of the supporting and olfactory cells observed in the present study was similar to that of supporting and olfactory cells in the various species described above.

The RE in the embryo was nearly flat, while in the adult, it was folded to produce numerous shallow grooves. According to the study of Parsons ('59), the folding of the RE in the snake occurred only in the late embryological stage. The functions of the RE are considered to be warmth, humidity and filtering of the inspired air. The folding of the RE is considered to fascilitate these functions.

In the present study, the RE in the snake was composed of columnar, mucous and basal cells. In case of light microscopy, it has generally been accepted that the $\mathrm{RE}$ is made up of the above three kinds of cells in various other species, as well as in the reptile (Parsons, '70). Besides the above three types of cells, recent transmission (Monteiro-Riviere and Popp, '84) and scanning electron microscopic studies (Popp and Martin, '84) in the rat, however, have shown the existence of several other types of cells: non-ciliated columnar, cuboidal, brush cells. According to Monteiro-Riviere and Popp ('84), these cells were all cylindrical ones extending from the free surface to the base of the RE. In the present light microscopic study, we could not detect these cells in the RE of the snake.
The structure of the RE, as determined by the Golgi method, has not heretofore been documented. In the Golgi preparations, only the columnar cells were impregnated. Morphological similarity between the columnar cells in the RE and the supporting ones in the $\mathrm{OE}$ suggests functional similarity between these two types of cells. The columnar cells observed in the Golgi preprations of the present study lacked cilia at the superficial-tips. In the Nissl preparations, the RE in the embryo of 9-13 $\mathrm{cm}$ in body length had no cilia at the surface. It could not be determined, however, whether the columnar cells lacking clia observed in the present study represent primitive columnar cells, the cilia of which were not yet developed or the cylindrical cells devoid of cilia noted in the electron microscopic studies (Monteiro-Riviere and Popp, '84; Popp and Martin, '84).

\section{Acknowledgement}

We thank to M. Ohara in Kyushu University for commenting on the manuscript, to T. Okubo, M. Kaneko and M. Hashiguchi for their excellent technical and photographic assistance. This work was supported, in part, by a Grant-in-Aid for Scientific Research (61570029) from the Japanese Ministry of Education, Science and Culture.

\section{References}

1) Allison, A. C.: The morphology of the olfactory system in the vertebrates. Biol. Rev., 28: 195-244, 1953.

2) Bellairs, A. d'A.: Observations on the snout of Varanus, and a comprison with that of other lizards and snakes. J. Anat., 83: 116-146, 1949.

3) Brunn, A. V.: Beiträge zur mikroskopischen Anatomie der menschlichen Nasenhöhle. Arch. Mikrosk. Anat., 39: 632-651, 1892.

4) Graziadei, P. P. C.: The olfactory mucosa of vertebrates. In "Handbook of Sensory Physiology, Vol. IV, Chemical Senses, Part I" (L. 
M. Beidler, ed.). pp. 27-58, Springer, Berlin, 1971.

5) Kleerekoper, H. and G. A. Van Erkel: The olfactory apparatus of Petromyzon marinus L. Canad. J. Zool., 38: 209-223, 1960.

6) Matthes, E.: Geruchsorgan. In "Handbuch der Vergleichenden Anatomie der Wirbeltiere. Bd. 2" (L. Bolk, E. Goppert, E. Kallius and W. Lubosch, eds.). pp. 879-948, Urban \& Schwarzenberg, Berlin, 1934.

7) Monteiro-Riviere, N. A. and J. A. Popp: Ultrastructural characterization of the nasal respiratory epithelium in the rat. Am. J. Anat., 169: 31-43, 1984.

8) Parsons, T. S.: Studies on the comparative embryology of the reptilian nose. Bull. Mus. Comp. Zool. Harvard, 120: 101-277, 1959.

9) Parsons, T. S.: The nose and Jacobson's organ. In "Biology of the Reptilia, Vol. 2, Morphology B" (F. Gans, ed.). pp. 99-191, Academic Press, London, 1970.

10) Popp, J. A. and J. T. Martin: Surface topo- graphy and distribution of cell types in the rat nasal respiratory epithelium: scanning electron microscopic observations. Am. J. Anat., 169: 425-436, 1984.

11) Ramón y Cajal, S.: Histologie du Système Nerveux de l'Homme et des Vertébrés. Tome II. pp. 647-649. Maloine, Paris, 1911.

12) Retzius, G.: Die Endingungsweise des Riechnerven. Biol. Untersuch. 3: 25-28, $1892 \mathrm{a}$.

13) Retzius, G.: Zur Kenntniss der Nervenendigungen in der Riechschleimhaut. Biol. Untersuch. 4: 62-64, $1892 \mathrm{~b}$.

14) Retzius, G.: Die Riechzellen der Ophidier in der Riechochleimhaut und im Jacobson'schen Organ. Biol. Untersuch. 6: 48-51, 1984.

15) Van Gehuchten, A.: Contributions a l'étude de la muquese olfactive chez les mammifères. La Cellule, 6: 395-408, 1890.

16) Wilson, J. A. F. and R. A. Westerman: The fine structure of the olfactory mucosa and nerve in the teleost Carassius carassius L. Z. Zellforsch. 83: 196-206, 1967. 


\section{Explanation of Figures}

\section{Plate 1}

A Photomicrograph of the snake olfactory mucosa. The mucosa is made up of the lamina propria mucosa (LPM) and overlying olfactory epithelium. The olfactory epithelium is a pseudostratified columnar one and is composed of the supporting, olfactory and basal cells, the nuclei of which are arranged in a laminar pattern with those of the supporting cells (NSC) are located most superficially, those of the olfactory cells (NOC) occupy the middle wide zone, while those of the basal cells (NBC) are seen in a row at the base of the epithelium. OG, olfactory gland. Cresylviolet stain. The scale line is $50 \mu \mathrm{m}$.

B Photomicrograph of the snake respiratory epithelium. The epithelium is a ciliated pseudostratified columnar one and is composed of columnar (CC), mucous (MC) and basal cells (BC). Crecylviolet stain. The scale line is $200 \mu \mathrm{m}$. 

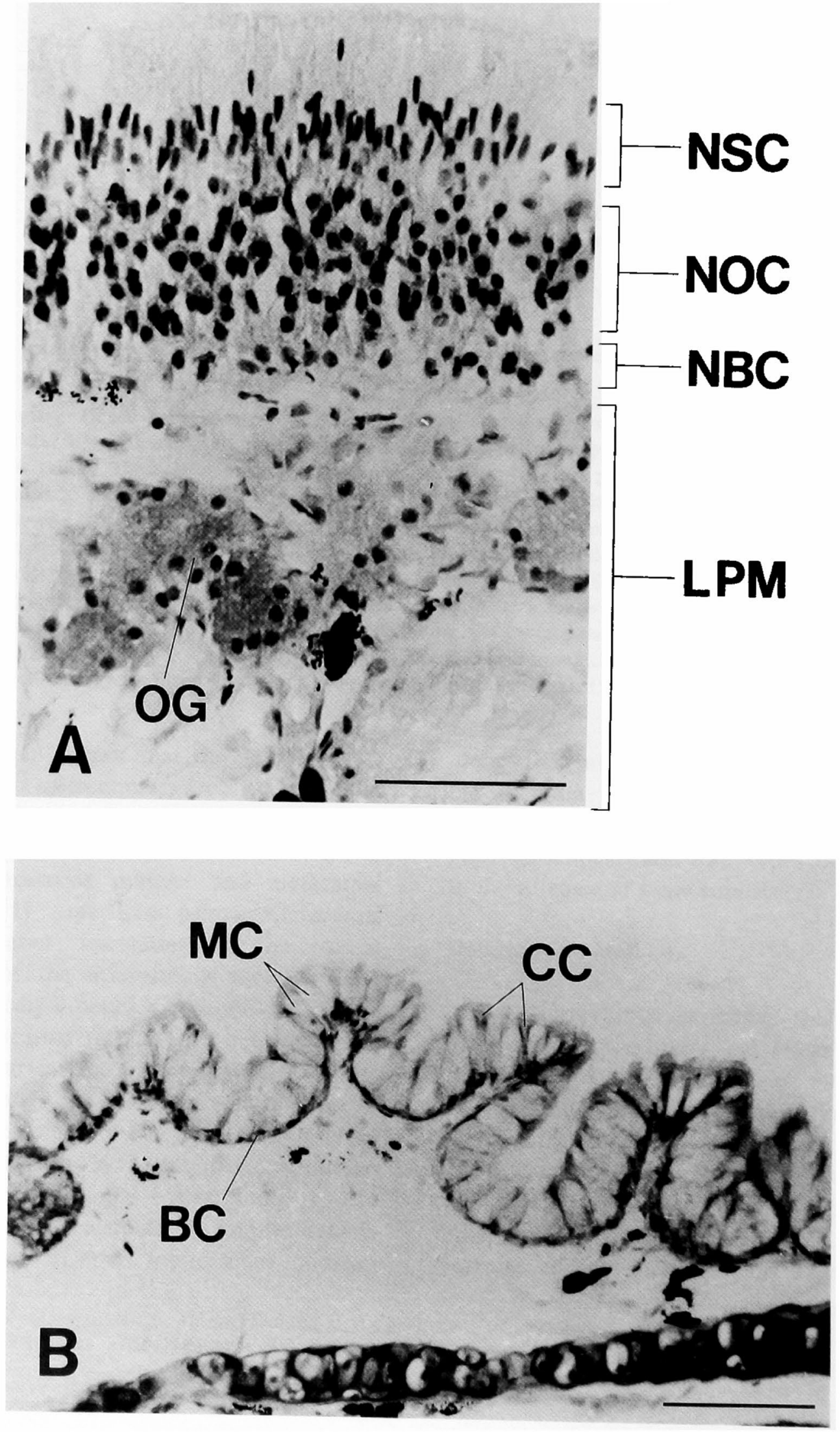